\title{
USING OF NANOTECHNOLOGY TO EVALUATE SOME POTASSIUM SOURCES AND METHODS APPLICATION ON SOIL AND PLANT
}

\author{
Eman M. Abd El-Razik, Zienab H. Abd El-Aziz and A. A. Akl \\ Soils, Water and Environment Res. Inst., Agric. Res. Center, Giza, Egypt \\ Received: Mar, 24, 2021 \\ Accepted: Apr. 19, 2021
}

\begin{abstract}
ABSTEACT: A field experiment was conducted on clay soil at Agriculture Research Center Station, Giza, Egypt, tomato (Solanum lycopersicum L., var. 448) plants were grown during the winter season of 2020-2021. Nanofertilizers were prepared by ballmilling and investigated by Transmission Electron Microscopy (TEM) measuring the potassium fertilizer particle sizes. Four treatments were apply as $100 \%$ of recommended dose (traditional $\mathrm{K}$ fertilizer-control treatment) $60,30,10 \% \mathrm{~K} \mathrm{NFs}$ and two sources of KNFs as K-humate(bio-source) and K-gluconate(organo-source), and two methods of $\mathrm{K}$ fertilizer apply as soil and foliar. The K-compound were sprayed with $1000 \mathrm{~g} / 400$ liter fed $^{-1}$. The aim of this study improving the use of potassium fertilizers by applying nanotechnology, raising tomato yields and reducing $\mathrm{K}$ loss. The data appeared that tomato yield and their quality showed more response to foliar application, K-humate at rate $10 \%$ of K NFs, and showed that the KNFs foliar spray application at rate of $10 \%$ reduced losses of $K$ through soil depths.
\end{abstract}

Key words: Potassium nanofertilizer, potassium sources, application methods, available K-losses, tomato plants, growth parameters and total yield,

\section{INTRODCUTION}

There is an urgent need to reduce the dangers arising from the excessive use of chemical fertilizers, as chemical fertilizers are applied in large quantities and with low efficiency, and this results in environmental pollution (Mir et al. 2018). Therefore, a serious agricultural technique must be applied that works to rationalize the use of fertilizers and with high efficiency, to reduce environmental damage (Mahmoud and Swaefy, 2020). The environmental pollution is increasing in developing countries where agriculture is the vertebral column of their national economy and faces many defies as the lack of new suitable soil and reduction of cultivable soil due to contend demands for economic development activities, ware reliance, penury, and malnutrition (Ditta and Arshad, 2016). Application of conventional fertilizers with low efficiency (20-50\%) and heavy cost increase in use rates have due to develop and promote the use of nanofertilizer (Aziz et al., 2006). Progression in the realms of science and technology could be a possible solution for raise the value in current production systems (Prasad et al., 2014). A considerable increase in agricultural production could be possible through employment of current knowledge in the realm of nanotechnology for efficient nutrient system (Liu and Lal, 2015), good plant protection practices, precision agriculture, and many others (Tarafdar, et al., 2013).Nanofertilizer are particles lies in the range of $1-100 \mathrm{~nm}$, which are more efficient than traditional chemical fertilizers due to the increase in use efficiency, reduce nutrient loss and reduce environmental pollution (Ditta and Arshad, 2016). 
Eman M. Abd El-Razik, et al.,

Potassium (K) has basic role in mitigation of biotic and abiotic stresses (Read et al., 2006), also it is enter in many processes in plant such as transport, assimilation, storage in tissue protein synthesis, photosynthesis, activation of enzymes and nitrogen fixation (Cakmak, 2005, Hawkesford et al., 2012 and Safavi, 2016), which affect on plant growth and yield components. Use of nanopotassium fertilizer increases the yield of the crop in soils with low fertility (Rajaei, 2010).

Tomato (Solanum lycopersicum L.) is one of the most widely consumed vegetable crops and grown at all world (Abdelmonaim, 2012). In Egypt, tomatoes have great economic importance in greenhouse and field production (Abuel-Heba et al., 2008).

The aim of this study: improving the use of potassium fertilizers by applying nanotechnology, improving and raising tomato yields, reducing soil and groundwater pollution.

\section{MATRIALS AND METHODES}

A field experiment was conducted on clay soil at Agriculture Research Center Station, Giza, Egypt, tomato plants(Solanum lycopersicum L., var. 448) were grown during the winter season of $2020-2021$. A spilt split plot design with three replicates was used to study some sources of potassium nanofertilizers (KNFs) as humate and gluconate on soil and plant. potassium sources were applied in main plots. Application methods were placed in sub-pots and four applications rates were located in sub-sub plots as $100 \%$ of full recommended dose of traditional $\mathrm{K}$ fertilizer (control), and KNFs as 60, 30 and $10 \%$ from recommended dose, which equal $48,28.8,14.4$ and $4.8 \mathrm{~kg}$ fed $^{-1}$, respectively). Potassium compound were sprayed with 1000 (control treatment $100 \%$ of traditional K fertilizer as potassium sulphate $48 \% \mathrm{~K}$ ), and $\mathrm{KNFs}$ as $600(60 \%), 300(30 \%)$ and $100(10 \%) \mathrm{g} / 400$ liter fed $^{-1}$ were applied at $15,30,45$ and 60 days after planting at randomly distributed in sub plots, followed spraying with standard methods to avoid osmosis effect on plants at early morning. Plants were transplanted into plots with an area of $12 \mathrm{~m}^{2}(3 \times 4 \mathrm{~m})$ each plot had twelve plants having spacing between rows and plants were 70 and $40 \mathrm{~cm}$, respectively. All agricultural practices were applied according to the recommendations of the ministry of agriculture, Egypt. Nanofertilizers were prepared by ball-milling (Eleyan et al., 2018) and Transmission Electron Microscopy (TEM) used to investigated and measuring the size of potassium fertilizers particle using JEOL transmission electron microscope (TEM) HRTEM, JEOL 3010 (Wang et al., 2014) as shown 1n Fig (1).

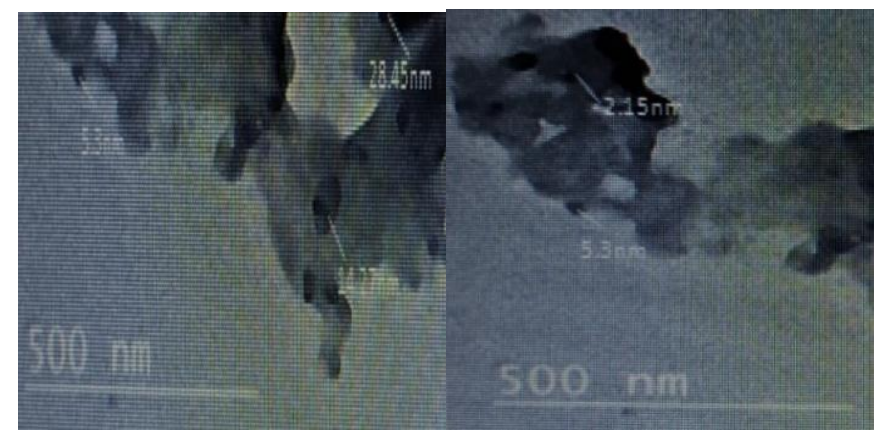

Fig (1): TEM images of (a) K-gluconate and K-humate NFs 
Soil samples were collected from all the studied treatments at depth of $0-30$, $30-60$ and $60-90 \mathrm{~cm}$ thoroughly homogenized, air dried and passed through $2 \mathrm{~mm}$ size sieve to determine organic matter according to Piper (1950). Soil pH (using pH meter model WTW Series $\mathrm{pH} 720$ ) was determined in 1:2.5 soil water suspensions according to the standard method described by Richards (1954). Total soluble salt (using EC meter model WTW Series Cond 720) were measured in soil paste extract as method described by Jackson et al. (1973). Total $\mathrm{CaCO}^{3}$ content and soluble cations and anions were carried out according to Jackson et al., (1973). Nitrogen by the micro Kjeldahl method according to AOAC (2012). Phosphorus was determined colorimetrically using spectrophotometer (model JENWAY6705UV/Vis) and potassium was determined using Flame-photometer (model JENWAYPFP7), according to Jackson et al. (1973). Available micronutrients were extracted by DTPA according to Lindsay and Norvell (1978) and determined using Atomic Absorption Spectrophotometer (model, analyticjenanovAA 350). Some physical and chemical properties of the experimental soil obtained are presented in Table (1).

At harvest stage, five plant samples were collected from each treatment of plot and were oven dried at $70{ }^{\circ} \mathrm{C}$, then fine grinded and were digested according to Jackson, (1973) to determine macro (N, $\mathrm{P}$, and $\mathrm{K}$ ), $\mathrm{Na}$ and micronutrients ( $\mathrm{Fe}, \mathrm{Mn}$ and $\mathrm{Zn}$ ) using micro-Kjelahel method, spectrophotometer, flam photometer and atomic spectrophotometer, respectively, according to AOAC (2012). Determined some of plant growth and biochemical parameters and yield productivity, fruit quality analysis as total acidity according to the method of Wills and Ku (2002), total soluble sugars according to Stewart (1974), Vitamin C according to Pearson (1970), Brix was made on the slide of the refractometer and the lid replaced, total soluble solids (brix ${ }^{\circ}$ ) according to Owoso et al., (2000), Penetrometer or Sclerometer to measuring fruit firmness to know force necessary to penetrate a plunger of known size into the pulp of the fruit. Photosynthetic pigments (chlorophyll-a, chlorophyll-b, total chlorophyll and carotenoids) were determined in fresh leaves according to Sumanta et al. (2014) using UV/VIS spectrophotometer (JENWAY 6705, UK).

Table (1): Some physical and chemical characteristics of the studied soil.

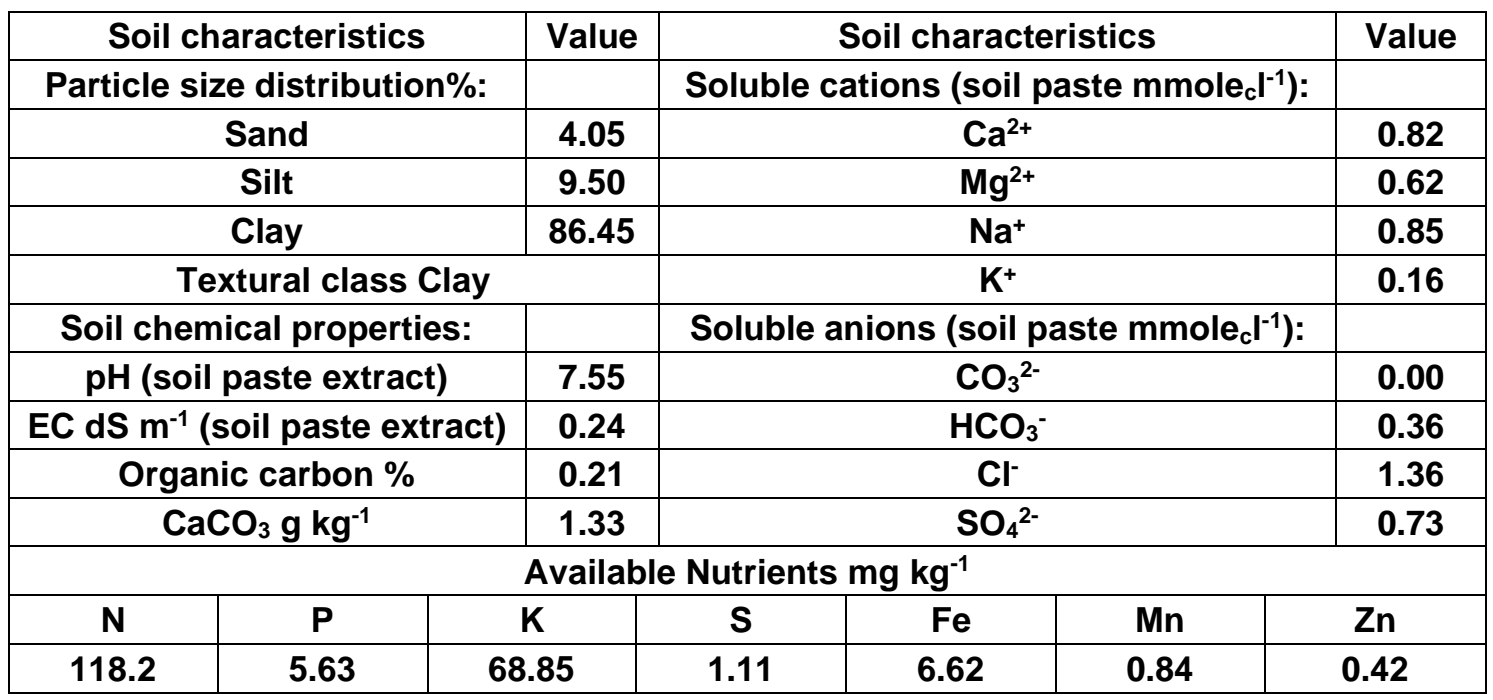


The data were statistically analyzed using one-way analysis of variance test by the least significant difference (LSD at 0.05 ) according to method described by Gomez and Gomez (1984) using IBM SPSS Statistics 20 program.

\section{RESULTS AND DISCUSSION}

Study was an attempt to know the best application methods (foliar or soil), improve tomato quality, productivity and least degree of pollution to the soil with some $\mathrm{K}$ FNs sources such as potassium humate(bio-K) and potassium gluconate (organo-K) (Shimaa, 2017). As the obtained results of winter season was not significantly different, their average was taken into consideration.

\section{Effect of some KNFs sources application on some plant growth characteristics of tomato plant:}

Data in Table (2) showed that the effect of KNFs application as soil and foliar spray addition, with different rates. The results revealed that, the K-humate NFs and K- gluconate NFs were significantly enhanced the growth parameters compared with control treatments.

As shown in the Table (2) the applied potassium in source of K-humate NFs led to enhancing the growth parameters of the tomato plant, and applied also as a spraying on the plant led to a better response on all growth parameters(Mahmoud etal.,2019). Also, applied K-humate as NFs at different rates under study gave a positive response at the rate of $10 \% \mathrm{~K}$-humate NFs(Mahmoud etal.,2017). Azarpour et al. (2012) studied the different K-sources and methods of applied and found that Khumate marked increases in plant height, fresh weight and dry matter content of tomato plants and values were $102.72 \mathrm{~cm}$, $2899 \mathrm{~kg} \mathrm{fed}^{-1}$ and $7.01 \%$, respectively, in compare with other treatments and control treatment (100 full recommended dose as traditional fertilizer) which recorded lowest values were $62.35 \mathrm{~cm}$, $1464 \mathrm{~kg} \mathrm{fed}^{-1}$ and $3.57 \%$, respectively, as the previous arrangement(Mahmoud and Swaefy, 2020).

The presented data showed that interaction analysis for K-humate NFs at foliar spray application and rate of $10 \%$ KNFs was superior to all other potassium sources and application methods used for tomato plant, where K-gluconate added as soil application and control treatment was inferior (Sher and Abdur, 2013).

\section{Effect of some KNFs sources on some fruit characteristics of tomato plant:}

The data in Table (3) indicated that adding NFs as K-humate with foliar spray application on the tomato plant gave a better result than K-gluconate organosource with soil application in terms on the characteristics of tomato plants and yield (Farnia and Ezatollah, 2015).

However, adding fertilizers at the nano size maximize the benefit of the fertilizer unit. While, choosing the appropriate fertilizer source, dose and suitable method to add, maximize the plant response (Bidari and Hebsur, 2011).

Fruit firmness and Fruit yield were as follows 27.17, 22.47, 11.25 fruit plant $^{-1}$, $9.45,7.31,6.43 \mathrm{~kg} \mathrm{~cm}^{-1}, 37.51,29.89$ and 9.63 ton fed $^{-1}$ for each of K-humate and Kgluconate at rate $10 \% \mathrm{KNFs}$ (in the case of adding the fertilizer foliar spray on plant) in compare with the control treatment, respectively, (Hosseini et al., 2013).

Interaction analysis showed that Khumate NFs with foliar spray application at rate of $10 \% \mathrm{KNFs}$ were superior, while application of K-gluconate NFs was 
Using of nanotechnology to evaluate some potassium sources and

inferior at both application methods used, as showed in Fig. (2). NFs increased the productivity of all most treatments in tomato plants, this mean that NFs could promote the production of plant (Nouraein, 2019).

Table (2): Effect of some KNFs sources on some fruit characteristics of plant.

\begin{tabular}{|c|c|c|c|c|c|}
\hline Methods(M) & $\begin{array}{c}\mathrm{K} \\
\text { sources(S) }\end{array}$ & Rates\%(R) & $\begin{array}{c}\text { Plant height } \\
\text { cm }\end{array}$ & $\begin{array}{c}\text { Fresh weight } \\
\mathrm{Kg} \mathrm{fed}^{-1}\end{array}$ & $\begin{array}{c}\text { Dry matter } \\
\%\end{array}$ \\
\hline \multirow{10}{*}{ Soil } & Control & 100 & 62.33 & 1359 & 3.55 \\
\hline & \multirow{4}{*}{ Humate } & 60 & 92.12 & 2474 & 4.64 \\
\hline & & 30 & 92.59 & 2475 & 5.11 \\
\hline & & 10 & 92.95 & 2477 & 5.47 \\
\hline & & Mean & 85.00 & 2196 & 4.69 \\
\hline & Control & 100 & 62.33 & 1359 & 3.55 \\
\hline & \multirow{4}{*}{ Gluconate } & 60 & 75.82 & 2021 & 3.85 \\
\hline & & 30 & 76.29 & 2024 & 4.32 \\
\hline & & 10 & 76.41 & 2025 & 4.86 \\
\hline & & Mean & 72.71 & 1857 & 4.15 \\
\hline \multicolumn{3}{|c|}{ Mean } & 78.86 & 2026.75 & 4.42 \\
\hline \multirow{10}{*}{ Foliar } & Control & 100 & 62.35 & 1464 & 3.57 \\
\hline & \multirow{4}{*}{ Humate } & 60 & 102.24 & 2897 & 6.16 \\
\hline & & 30 & 102.72 & 2898 & 6.65 \\
\hline & & 10 & 103.07 & 2899 & 7.01 \\
\hline & & Mean & 92.60 & 2540 & 5.85 \\
\hline & Control & 100 & 62.35 & 1464 & 3.57 \\
\hline & \multirow{4}{*}{ Gluconate } & 60 & 85.24 & 2104 & 4.80 \\
\hline & & 30 & 85.71 & 2106 & 4.64 \\
\hline & & 10 & 86.07 & 2108 & 5.63 \\
\hline & & Mean & 79.84 & 1946 & 4.66 \\
\hline \multicolumn{3}{|c|}{ Mean } & 86.22 & 2242.50 & 5.25 \\
\hline \multirow{2}{*}{$\begin{array}{l}\text { Mean of } \\
\text { K sources }\end{array}$} & \multicolumn{2}{|c|}{ Humate } & 88.80 & 2367.88 & 5.27 \\
\hline & \multicolumn{2}{|c|}{ Gluconate } & 76.28 & 1901.38 & 4.40 \\
\hline \multirow{4}{*}{$\begin{array}{l}\text { Mean of } \\
\text { rates } \%\end{array}$} & \multicolumn{2}{|c|}{100} & 62.34 & 1411.5 & 3.56 \\
\hline & \multicolumn{2}{|c|}{60} & 88.86 & 2374.00 & 4.86 \\
\hline & \multicolumn{2}{|c|}{30} & 89.33 & 2375.75 & 5.18 \\
\hline & \multicolumn{2}{|c|}{10} & 89.63 & 2377.25 & 5.74 \\
\hline & \multicolumn{2}{|c|}{ M } & 1.5 & 1.8 & 0.5 \\
\hline & \multicolumn{2}{|c|}{ S } & 3 & 3.3 & 1.5 \\
\hline & \multicolumn{2}{|c|}{$\mathbf{R}$} & 0.9 & 1.1 & 0.6 \\
\hline LSD at 0.05 & \multicolumn{2}{|c|}{ MS } & 0.7 & 0.8 & 0.7 \\
\hline & \multicolumn{2}{|c|}{ MR } & 2.2 & 1.3 & 1.5 \\
\hline & \multirow{2}{*}{\multicolumn{2}{|c|}{ SR }} & 0.9 & 0.7 & 0.7 \\
\hline & & & 4.2 & 6.6 & 0.8 \\
\hline
\end{tabular}


Eman M. Abd El-Razik, et al.,

Table (3): Effect of some KNFs sources on some fruit characteristics of plant.

\begin{tabular}{|c|c|c|c|c|c|}
\hline Methods(M) & $\begin{array}{c}\mathrm{K} \\
\text { sources(S) }\end{array}$ & Rates\%(R) & $\begin{array}{l}\text { No. of fruit } \\
\text { plant }^{-1}\end{array}$ & $\begin{array}{l}\text { Fruit firmness } \\
\qquad\left(\mathrm{kg} \mathrm{cm}^{-1}\right)\end{array}$ & $\begin{array}{l}\text { Fruit yield } \\
\text { (ton fed }^{-1} \text { ) }\end{array}$ \\
\hline \multirow{10}{*}{ Soil } & Control & 100 & 11.53 & 6.46 & 9.06 \\
\hline & \multirow{4}{*}{ Humate } & 60 & 21.82 & 7.50 & 28.31 \\
\hline & & 30 & 22.29 & 7.97 & 28.78 \\
\hline & & 10 & 22.65 & 8.33 & 29.14 \\
\hline & & Mean & 19.57 & 7.57 & 23.82 \\
\hline & Control & 100 & 11.53 & 6.46 & 9.06 \\
\hline & \multirow{4}{*}{ Gluconate } & 60 & 18.62 & 6.20 & 26.52 \\
\hline & & 30 & 19.09 & 6.97 & 26.99 \\
\hline & & 10 & 19.45 & 7.33 & 27.35 \\
\hline & & Mean & 17.17 & 6.74 & 22.48 \\
\hline \multicolumn{3}{|c|}{ Mean } & 18.37 & 7.15 & 23.15 \\
\hline \multirow{10}{*}{ Foliar } & Control & 100 & 11.25 & 6.43 & 9.63 \\
\hline & \multirow{4}{*}{ Humate } & 60 & 26.34 & 8.62 & 36.68 \\
\hline & & 30 & 26.81 & 9.09 & 37.15 \\
\hline & & 10 & 27.17 & 9.45 & 37.51 \\
\hline & & Mean & 22.89 & 8.40 & 30.24 \\
\hline & Control & 100 & 11.25 & 6.43 & 9.63 \\
\hline & \multirow{4}{*}{ Gluconate } & 60 & 21.64 & 6.48 & 29.05 \\
\hline & & 30 & 22.11 & 6.95 & 29.53 \\
\hline & & 10 & 22.47 & 7.31 & 29.89 \\
\hline & & Mean & 19.37 & 6.79 & 24.53 \\
\hline \multicolumn{3}{|c|}{ Mean } & 21.13 & 7.60 & 27.38 \\
\hline \multirow{2}{*}{$\begin{array}{c}\text { Mean of } \\
\text { K sources }\end{array}$} & \multicolumn{2}{|c|}{ Humate } & 21.23 & 7.98 & 27.03 \\
\hline & \multicolumn{2}{|c|}{ Gluconate } & 18.27 & 6.77 & 23.50 \\
\hline \multirow{4}{*}{$\begin{array}{l}\text { Mean of } \\
\text { rates \% }\end{array}$} & \multicolumn{2}{|c|}{100} & 11.39 & 6.45 & 9.35 \\
\hline & \multicolumn{2}{|c|}{60} & 22.11 & 7.20 & 30.14 \\
\hline & \multicolumn{2}{|c|}{30} & 22.58 & 7.75 & 30.61 \\
\hline & \multicolumn{2}{|c|}{10} & 22.94 & 8.11 & 30.97 \\
\hline \multirow{7}{*}{ LSD at 0.05} & \multicolumn{2}{|c|}{$M$} & 1.7 & 2.0 & 0.9 \\
\hline & \multicolumn{2}{|c|}{$S$} & 0.5 & 0.7 & 0.5 \\
\hline & \multicolumn{2}{|c|}{$\mathbf{R}$} & 0.9 & 1.0 & 0.5 \\
\hline & \multicolumn{2}{|c|}{ MS } & 1.4 & 1.4 & 1.1 \\
\hline & \multicolumn{2}{|c|}{ MR } & 1.3 & 0.9 & 1.2 \\
\hline & \multicolumn{2}{|c|}{ SR } & 0.5 & 0.7 & 0.3 \\
\hline & \multicolumn{2}{|c|}{ MSR } & 0.8 & 1.4 & 0.6 \\
\hline
\end{tabular}




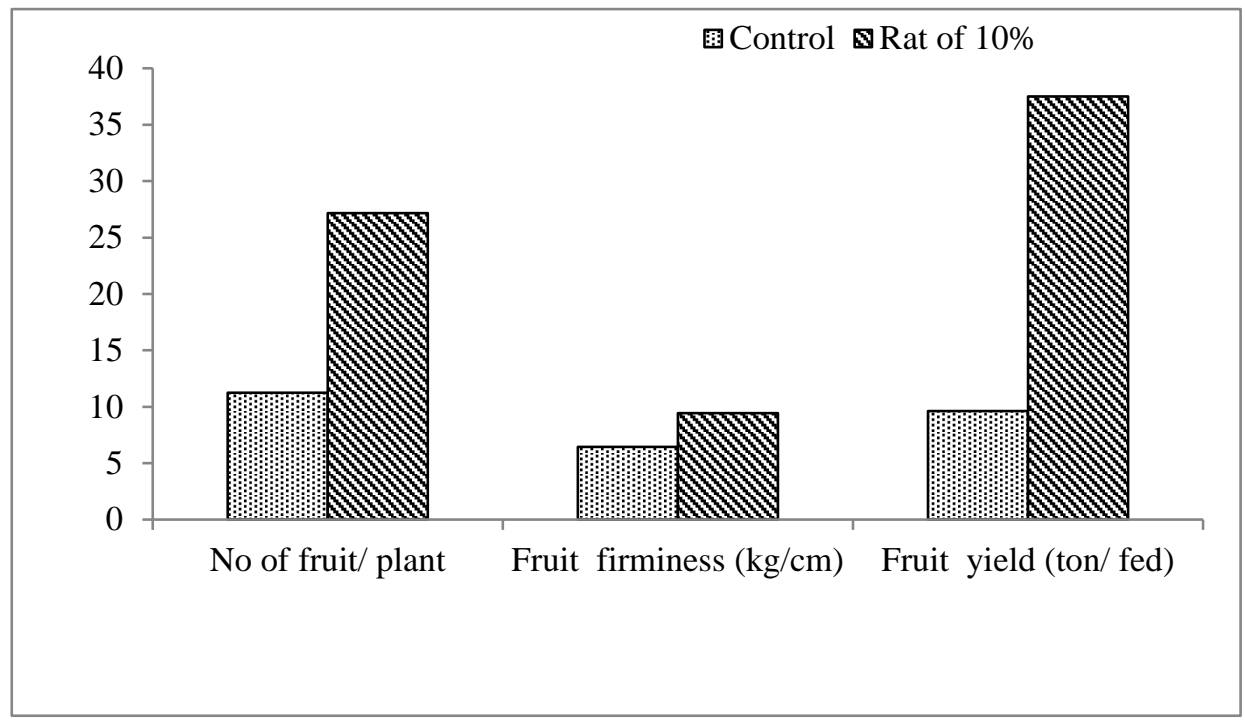

Fig (2): Compare between control and foliar application with KNFs at rate of $10 \%$ application for fruit and some yield parameters of tomato plans.

\section{Effect of some KNFs sources on some on macro- nutrients content of tomato fruit:}

The results in Table (4) show the macro-nutrients content of tomato fruits, which reflects the nutritional status of the plant.

Data was found that following the appropriate methods such as type of fertilizer source, method of addition, the appropriate fertilizer rate for adding and using nanofertilizer led to an increase in the plant's response to the accumulation of $N, P$ and $K$ in the vegetative parts of plant and then remobilize and translocate to the growing fruits.

The data presented Table (4) showed that the difference in the plant's response to applying potassium as K-humate or organo-fertilizer (K-gluconate) and also if the addition was soil add or foliar spray application at different rates compared to the control treatment, the K-humate NFs was the best and showed a clear superiority of tomato effects with values of $2.94,2.21$ and $3.79 \%$ for K-humate NFs while the values were 2.5, 1.60 and $3.24 \%$ tefor K-gluconate NFs using a foliar spray application at a rate of $10 \%$, but the values of control treatment were 1.55, 1.26 and $2.85 \%$, respectively. NFs treatments induced a significant improvement in nutrient content in tomato plants compared to control treatment (Ditta and Arshad, 2016).

Finally, the results showed that responses of $N, P$ and $K$ content in tomato fruit seemed to be more efficient with K- humate NFs of foliar spray application. Furthermore, the same attitude previously mentioned with tomato plant growth parameter was more rational and more related to $\mathrm{N}, \mathrm{P}$ and $\mathrm{K}$ contents in tomato fruit (Sajyan et al., 2020).

\section{Effect of some K NFs sources on some on micro- nutrients content of tomato fruit:}

Data recorded in Table (5) revealed differences between both studied sources of KNFs, and relationship between micronutrients status and tomato fruit. The K-humate NFs seemed to be preferable. Further, the micronutrient elements content as Fe, Mn 
Eman M. Abd El-Razik, et al.,

and $\mathrm{Zn}$ in tomato fruits due to K-humate application as K-humate NFs treatment were considerably better than that of the organo-oneNFs (K-gluconate). The mean values were 89.67 and $63.96 \mathrm{mg} \mathrm{kg}^{-1}$ for iron, $\quad 69.39$ and $64.36 \mathrm{mgkg}^{-1}$ for manganese and 42.94 and $31.76 \mathrm{mg} \mathrm{kg}^{-1}$ for zinc, respectively (Delfani et al., 2014).

Table (4): Effect of some KNFs sources on some macro- nutrients content of fruits.

\begin{tabular}{|c|c|c|c|c|c|}
\hline Methods(M) & K sources(S) & Rates\%(R) & $\mathbf{N} \%$ & $\mathbf{P} \%$ & $\mathrm{~K} \%$ \\
\hline \multirow{10}{*}{ Soil } & Control & 100 & 1.36 & 1.12 & 2.76 \\
\hline & \multirow{4}{*}{ Humate } & 60 & 1.79 & 1.22 & 2.63 \\
\hline & & 30 & 2.26 & 1.49 & 3.10 \\
\hline & & 10 & 2.62 & 1.85 & 3.46 \\
\hline & & Mean & 2.01 & 1.37 & 2.99 \\
\hline & Control & 100 & 1.36 & 1.12 & 2.76 \\
\hline & \multirow{4}{*}{ Gluconate } & 60 & 1.46 & 1.02 & 2.22 \\
\hline & & 30 & 1.92 & 1.12 & 2.69 \\
\hline & & 10 & 2.28 & 1.43 & 3.05 \\
\hline & & Mean & 1.76 & 1.02 & 2.68 \\
\hline \multicolumn{3}{|c|}{ Mean } & 1.88 & 1.20 & 2.83 \\
\hline \multirow{10}{*}{ Foliar } & Control & 100 & 1.55 & 1.26 & 2.85 \\
\hline & \multirow{4}{*}{ Humate } & 60 & 2.11 & 1.38 & 2.96 \\
\hline & & 30 & 2.58 & 1.85 & 3.42 \\
\hline & & 10 & 2.94 & 2.21 & 3.78 \\
\hline & & Mean & 2.30 & 1.68 & 3.25 \\
\hline & Control & 100 & 1.55 & 1.26 & 2.85 \\
\hline & \multirow{4}{*}{ Gluconate } & 60 & 1.68 & 1.17 & 2.40 \\
\hline & & 30 & 2.14 & 1.24 & 2.87 \\
\hline & & 10 & 2.50 & 1.60 & 3.24 \\
\hline & & Mean & 1.97 & 1.22 & 2.84 \\
\hline \multicolumn{3}{|c|}{ Mean } & 2.13 & 1.45 & 3.05 \\
\hline \multirow{2}{*}{$\begin{array}{c}\text { Mean of } \\
\text { K sources }\end{array}$} & \multicolumn{2}{|c|}{ Humate } & 2.15 & 1.52 & 3.12 \\
\hline & \multicolumn{2}{|c|}{ Gluconate } & 1.86 & 1.12 & 2.76 \\
\hline \multirow{4}{*}{$\begin{array}{c}\text { Mean of } \\
\text { rates\% }\end{array}$} & \multicolumn{2}{|c|}{100} & 1.46 & 1.19 & 2.81 \\
\hline & \multicolumn{2}{|c|}{60} & 1.79 & 1.20 & 2.55 \\
\hline & \multicolumn{2}{|c|}{30} & 2.23 & 1.40 & 3.02 \\
\hline & \multicolumn{2}{|c|}{10} & 2.59 & 1.77 & 3.38 \\
\hline & \multicolumn{2}{|c|}{$\mathbf{M}$} & 0.5 & 0.7 & 0.03 \\
\hline & \multicolumn{2}{|c|}{ S } & 0.5 & 0.6 & 0.2 \\
\hline & \multicolumn{2}{|c|}{$\mathbf{R}$} & 0.6 & 0.8 & 0.02 \\
\hline LSD at 0.05 & \multicolumn{2}{|c|}{ MS } & 0.3 & 0.4 & 0.1 \\
\hline & \multicolumn{2}{|c|}{ MR } & 0.3 & 0.6 & 0.1 \\
\hline & \multicolumn{2}{|c|}{ SR } & 0.4 & 0.5 & 0.4 \\
\hline & \multicolumn{2}{|c|}{ MSR } & 0.4 & 0.6 & 0.04 \\
\hline
\end{tabular}


Using of nanotechnology to evaluate some potassium sources and

Table (5): Effect of some KNFs sources on some micro- nutrients content of fruits.

\begin{tabular}{|c|c|c|c|c|c|}
\hline Methods(M) & K sources(S) & Rates\%(R) & Fe $\mathrm{mg} \mathrm{kg}^{-1}$ & Mn mg kg-1 & Zn mg kg-1 \\
\hline \multirow{10}{*}{ Soil } & Control & 100 & 46.13 & 52.33 & 23.43 \\
\hline & \multirow{4}{*}{ Humate } & 60 & 78.12 & 66.32 & 37.92 \\
\hline & & 30 & 78.59 & 66.79 & 33.39 \\
\hline & & 10 & 78.95 & 67.15 & 38.75 \\
\hline & & Mean & 70.45 & 63.15 & 33.37 \\
\hline & Control & 100 & 46.13 & 52.33 & 23.43 \\
\hline & \multirow{4}{*}{ Gluconate } & 60 & 64.82 & 60.32 & 31.62 \\
\hline & & 30 & 65.29 & 60.79 & 32.09 \\
\hline & & 10 & 65.65 & 61.15 & 32.45 \\
\hline & & Mean & 60.47 & 58.65 & 29.90 \\
\hline \multicolumn{3}{|c|}{ Mean } & 65.46 & 60.90 & 31.64 \\
\hline \multirow{10}{*}{ Foliar } & Control & 100 & 55.23 & 50.53 & 23.63 \\
\hline & \multirow{4}{*}{ Humate } & 60 & 88.84 & 75.24 & 48.94 \\
\hline & & 30 & 89.31 & 75.71 & 49.41 \\
\hline & & 10 & 89.67 & 76.07 & 49.77 \\
\hline & & Mean & 80.76 & 69.39 & 42.94 \\
\hline & Control & 100 & 55.23 & 50.53 & 23.63 \\
\hline & \multirow{4}{*}{ Gluconate } & 60 & 66.44 & 68.54 & 34.04 \\
\hline & & 30 & 66.91 & 69.01 & 34.51 \\
\hline & & 10 & 67.27 & 69.37 & 34.87 \\
\hline & & Mean & 63.96 & 64.36 & 31.76 \\
\hline \multicolumn{3}{|c|}{ Mean } & 72.36 & 66.88 & 37.35 \\
\hline \multirow{2}{*}{$\begin{array}{l}\text { Mean of } \\
\text { K sources }\end{array}$} & \multicolumn{2}{|c|}{ Humate } & 75.61 & 66.27 & 38.16 \\
\hline & \multicolumn{2}{|c|}{ Gluconate } & 62.22 & 61.51 & 30.83 \\
\hline \multirow{4}{*}{$\begin{array}{l}\text { Mean of } \\
\text { rates \% }\end{array}$} & \multicolumn{2}{|c|}{100} & 50.68 & 51.43 & 23.53 \\
\hline & \multicolumn{2}{|c|}{60} & 74.56 & 67.61 & 38.13 \\
\hline & \multicolumn{2}{|c|}{30} & 75.03 & 68.08 & 37.35 \\
\hline & \multicolumn{2}{|c|}{10} & 75.39 & 68.44 & 38.96 \\
\hline \multirow{7}{*}{ LSD at 0.05} & \multicolumn{2}{|c|}{$\mathbf{M}$} & 2.3 & 2.4 & 1.1 \\
\hline & \multicolumn{2}{|c|}{ S } & 6.0 & 9.2 & 2.5 \\
\hline & \multicolumn{2}{|c|}{$\mathbf{R}$} & 2.2 & 2.3 & 2.1 \\
\hline & \multicolumn{2}{|c|}{ MS } & 1.4 & 2.2 & 2.5 \\
\hline & \multicolumn{2}{|c|}{ MR } & 5.2 & 5.5 & 2.3 \\
\hline & \multicolumn{2}{|c|}{ SR } & 1.3 & 2.1 & 5.3 \\
\hline & \multicolumn{2}{|c|}{ MSR } & 3.2 & 3.4 & 2.2 \\
\hline
\end{tabular}


Furthermore, foliar spray application was more suitable than that of soil application, most supposedly that occurred because ease of fertilizer absorption by the plant without loss, as occurs in soil application, this is explain the improvement occurred for both growths of plants and macro-nutrients status.Generally, the results appeared that the high contents of micronutrient in tomato fruit were with values $89.67,76.07$ and $49,77 \mathrm{mg} \mathrm{kg}^{-1}$ at $10 \%$ rate of $\mathrm{K}$ humate NFs and foliar application for $\mathrm{Fe}$, $\mathrm{Mn}$ and $\mathrm{Zn}$, respectively, (Afify et al., 2019).

\section{Effect of some KNFs sources on} some total soluble solids and titratable acidity of tomato fruit quality:

Usually evaluated the quality of plant production according to the purpose of using the plant. Anyway, nutrition and other environmental factors are highly affecting through effecting biochemical of physiological processes. Data in Table (6) showed that some differences between both K-humate and K-gluconate sources, but K-humate NFs was relatively considered the best treatment. Also, the results showed that the response of tomato plants to K-humate more than Kgluconate, such this response may be due to the suitability of source application for total soluble solids and titratable acidity of tomato fruit (Ferrara and Brunetti, 2010). The applied method of potassium was more effective with foliar spray being more favorable than soil application. On other hand, the values were $6.97,5.27^{\circ} \mathrm{Brix}, 3849$ and 2138 $\mathrm{mg} \mathrm{L}^{-1}$ for TSS and respectively, at $10 \%$ rate of K-humate NFs with foliar application (Merghany et al., 2019).

Interaction analysis obtained in the previous Table showed that total soluble solids and titratable acidity were most affected by K-humate and K-gluconate at foliar spray application were. But, the effect of k-gluconate NFs form at a soil application method was inferior.

\section{Effect of some K NFs sources on some biochemical parameters of tomato leaves:}

Data presented in Table (7) showed the same behavior mentioned previously for all plant parameters under study. There was a positive response of plant pigments to K-source NFs and methods of application, especially K-humate, was more essential compared to organoKNFs with all plant pigments contents under study. Whereas, the data revealed that KNFs at all sources and rates produced the highest total chlorophyll and carotenoids content values compared to the control treatment with mean ranged between 2083 to 2843 and 1089 to $1494 \mu \mathrm{g} \mathrm{g}^{-1}$ fresh leaves, respectively (Salama, 2012). At rate of $10 \%$, K-humate NFs with foliar spray application recorded high positive response with value were 2843 and 289 $\mu \mathrm{g} \mathrm{g}^{-1}$ fresh leaves for total chlorophyll and carotenoids content, respectively (Afify et al., 2019).

On the other hand, applied K-humate NFs, as foliar spray was high positive response compared to soil application. Where total chlorophyll and carotenoids content increased due to the plant photothynses, rate of plant growth, protein synthesis and activated biomass production which stimulates plant growth and ultimately increases plant growth (Merghany et al., 2019).

Nanoparticles improve photosynthesis and reduce respiration rate, which increases the content of tomato plants from total chlorophyll (Abdel Wahab et al., 2019).

Interaction analysis for the appeared data in Fig (3) stated that foliar spray application of K-humate NFs seemed to be the high response and $\mathrm{K}$-gluconate NFs in soil application was less response. 
Using of nanotechnology to evaluate some potassium sources and

Table (6): Effect of some KNFs sources on some total soluble solids and total acidity of fruit

\begin{tabular}{|c|c|c|c|c|}
\hline Methods(M) & K sources(S) & Rates\%(R) & TSS (Brix) & Total acidity $\mathrm{mg} \mathrm{l}^{-1}$ \\
\hline \multirow{10}{*}{ Soil } & Control & 100 & 3.93 & 1322 \\
\hline & \multirow{4}{*}{ Humate } & 60 & 4.42 & 2214 \\
\hline & & 30 & 4.89 & 2215 \\
\hline & & 10 & 5.25 & 2217 \\
\hline & & Mean & 4.62 & 1992.00 \\
\hline & Control & 100 & 3.93 & 1322 \\
\hline & \multirow{4}{*}{ Gluconate } & 60 & 3.52 & 2017 \\
\hline & & 30 & 3.99 & 2018 \\
\hline & & 10 & 4.35 & 2019 \\
\hline & & Mean & 3.95 & 1844.00 \\
\hline \multicolumn{3}{|c|}{ Mean } & 4.29 & 1918.00 \\
\hline \multirow{10}{*}{ Foliar } & Control & 100 & 4.05 & 1331 \\
\hline & \multirow{4}{*}{ Humate } & 60 & 6.14 & 3846 \\
\hline & & 30 & 6.61 & 3848 \\
\hline & & 10 & 6.97 & 3849 \\
\hline & & Mean & 5.94 & 3218.50 \\
\hline & Control & 100 & 4.05 & 1331 \\
\hline & \multirow{4}{*}{ Gluconate } & 60 & 4.44 & 2134 \\
\hline & & 30 & 4.91 & 2137 \\
\hline & & 10 & 5.27 & 2138 \\
\hline & & Mean & 4.67 & 1935.00 \\
\hline \multicolumn{3}{|c|}{ Mean } & 5.31 & 2576.75 \\
\hline \multirow{2}{*}{$\begin{array}{c}\text { Mean of K } \\
\text { sources }\end{array}$} & \multicolumn{2}{|c|}{ Humate } & 5.28 & 2605.25 \\
\hline & \multicolumn{2}{|c|}{ Gluconate } & 4.31 & 1889.50 \\
\hline \multirow{4}{*}{$\begin{array}{c}\text { Mean of Rates } \\
\%\end{array}$} & \multicolumn{2}{|c|}{100} & 3.99 & 1326.50 \\
\hline & \multicolumn{2}{|c|}{60} & 4.63 & 2552.75 \\
\hline & \multicolumn{2}{|c|}{30} & 5.10 & 2554.50 \\
\hline & \multicolumn{2}{|c|}{10} & 5.46 & 2555.75 \\
\hline \multirow{7}{*}{ LSD at 0.05} & \multicolumn{2}{|c|}{$\mathbf{M}$} & 6.2 & 7.2 \\
\hline & \multicolumn{2}{|c|}{$S$} & 1.7 & 3.7 \\
\hline & \multicolumn{2}{|c|}{$\mathbf{R}$} & 5.4 & 9.1 \\
\hline & \multicolumn{2}{|c|}{ MS } & 10.5 & 6.6 \\
\hline & \multicolumn{2}{|c|}{ MR } & 3.5 & 6.5 \\
\hline & \multicolumn{2}{|c|}{ SR } & 9.2 & 3.7 \\
\hline & \multicolumn{2}{|c|}{ MSR } & 4.5 & 5.7 \\
\hline
\end{tabular}


Eman M. Abd El-Razik, et al.,

Table (7): Effect of some K NFs sources on some biochemical parameters $(\mu \mathrm{g} / \mathrm{g})$ of leaves

\begin{tabular}{|c|c|c|c|c|c|c|}
\hline Methods(M) & K sources(S) & Rates\%(R) & Ch a & \multicolumn{2}{|c|}{$\mu \mathrm{g} \mathrm{g}^{-1}$ fresh leaves } & Carotenoid \\
\hline \multirow{10}{*}{ Soil } & Control & 100 & 1003 & 603 & 1606 & 156 \\
\hline & \multirow{4}{*}{ Humate } & 60 & 1803 & 789 & 2592 & 276 \\
\hline & & 30 & 1805 & 792 & 2597 & 275 \\
\hline & & 10 & 1808 & 795 & 2603 & 278 \\
\hline & & Mean & 1604.75 & 744.75 & 2349.50 & 246.25 \\
\hline & Control & 100 & 1003.00 & 603.00 & 1606.00 & 156.00 \\
\hline & \multirow{4}{*}{ Gluconate } & 60 & 1553.00 & 684.00 & 2237.00 & 198.00 \\
\hline & & 30 & 1556.00 & 688.00 & 2244.00 & 201.00 \\
\hline & & 10 & 1557.00 & 689.00 & 2246.00 & 204.00 \\
\hline & & Mean & 1417.25 & 666.00 & 2083.25 & 189.75 \\
\hline \multicolumn{3}{|c|}{ Mean } & 1511.00 & 705.38 & 2216.38 & 218.00 \\
\hline \multirow{10}{*}{ Foliar } & Control & 100 & 1005.00 & 610.00 & 1615.00 & 151.00 \\
\hline & \multirow{4}{*}{ Humate } & 60 & 1908.00 & 1338.00 & 3246.00 & 333.00 \\
\hline & & 30 & 1912.00 & 1341.00 & 3253.00 & 334.00 \\
\hline & & 10 & 1915.00 & 1344.00 & 3259.00 & 337.00 \\
\hline & & Mean & 1685.00 & 1158.25 & 2843.25 & 288.75 \\
\hline & Control & 100 & 1005.00 & 610.00 & 1615.00 & 151.00 \\
\hline & \multirow{4}{*}{ Gluconate } & 60 & 1652.00 & 985.00 & 2637.00 & 222.00 \\
\hline & & 30 & 1955.00 & 987.00 & 2942.00 & 222.00 \\
\hline & & 10 & 1957.00 & 989.00 & 2946.00 & 225.40 \\
\hline & & Mean & 1642.25 & 892.75 & 2535.00 & 205.10 \\
\hline \multicolumn{3}{|c|}{ Mean } & 1662.63 & 410.20 & 1663.63 & 247.08 \\
\hline \multirow{2}{*}{$\begin{array}{c}\text { Mean of } \\
\mathrm{K} \text { sources }\end{array}$} & \multicolumn{2}{|c|}{ Humate } & 1644.88 & 951.50 & 2596.38 & 267.50 \\
\hline & \multicolumn{2}{|c|}{ Gluconate } & 1529.75 & 779.38 & 2309.13 & 451.00 \\
\hline \multirow{4}{*}{$\begin{array}{l}\text { Mean of } \\
\text { rates \% }\end{array}$} & \multicolumn{2}{|c|}{100} & 1004.00 & 606.50 & 1610.50 & 153.50 \\
\hline & \multicolumn{2}{|c|}{60} & 3458.00 & 1898.00 & 5356.00 & 257.25 \\
\hline & \multicolumn{2}{|c|}{30} & 1807.00 & 952.00 & 2759.00 & 258.00 \\
\hline & \multicolumn{2}{|c|}{10} & 1809.25 & 954.25 & 2763.50 & 261.10 \\
\hline \multirow{7}{*}{\multicolumn{2}{|c|}{ LSD at 0.05}} & $\mathbf{M}$ & 10.0 & 30.0 & 15.0 & 25.0 \\
\hline & & $S$ & 2.5 & 5.3 & 10.0 & 50.0 \\
\hline & & $\mathbf{R}$ & 10.0 & 12.0 & 4.8 & 10.0 \\
\hline & & MS & 2.5 & 5.9 & 1.5 & 12.5 \\
\hline & & MR & 10.0 & 6.3 & 7.2 & 2.5 \\
\hline & & SR & 5.5 & 7.2 & 4.5 & 5.8 \\
\hline & & MSR & 10.0 & 55.0 & 5.2 & 15.0 \\
\hline
\end{tabular}

$\mathrm{Chl} \mathbf{a}=$ Chlorophyll $\mathrm{a}, \mathrm{Chl} \mathrm{b}=$ Chlorophyll $\mathrm{b}$ and $\mathrm{Chl} \mathrm{T}=$ total Chlorophyll 


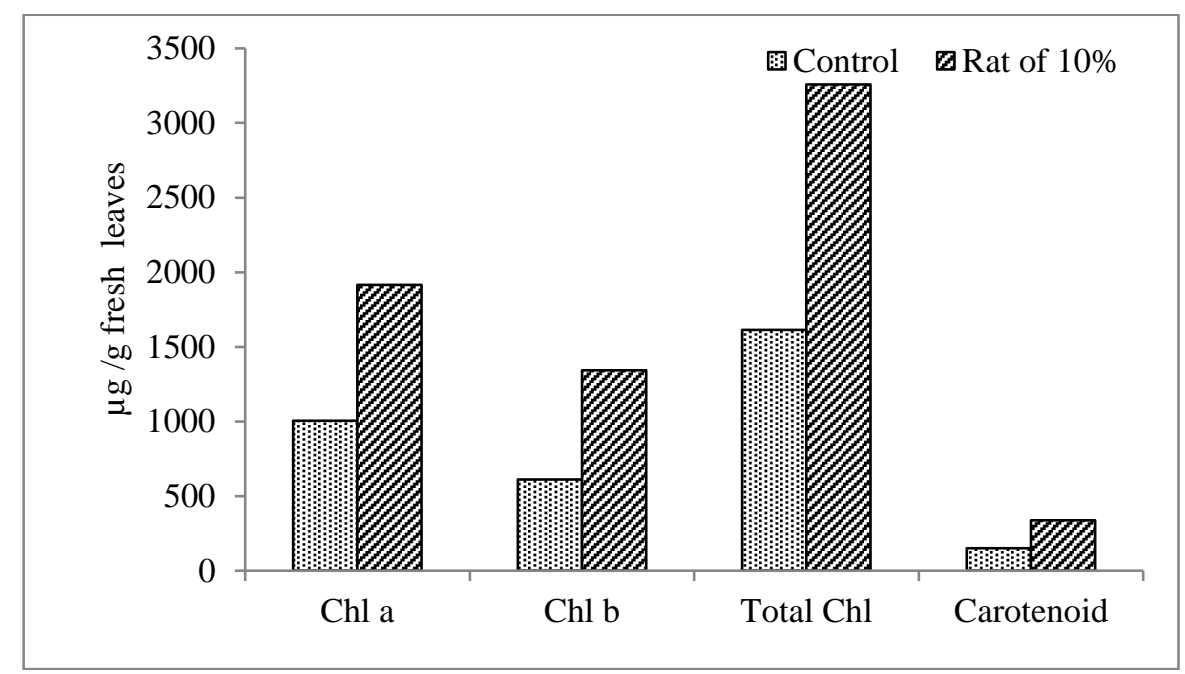

Fig. (3): Compare between control and foliar application with K-humate KNFs at rate of $10 \%$ for same biochemical plant parameters of tomato plants.

Effect of some KNFs sources on total soluble sugars and vitamin C of tomato fruit quality:

Data in Table (8) showed that significant differences between method of applied KNFs source, K-humate NFs and KNFs rate. However, data showed that K-humate sprayed at rate of $10 \%$, total sugar and vitamin C content was more than that one produced from another source as organo-KNFs with values were $80.05 \mathrm{mg} \mathrm{g}^{-1} \mathrm{dwt}$ and 283.17 $\mathrm{mg} 100 \mathrm{~cm}^{-3}$ juice, respectively. Thus, the results of total soluble sugars and vitamin $\mathrm{C}$ appeared an expected trend for foliar spray application method which taken a suitable effect on the total sugar content and vitamin C (Chapagain and Wiesman, 2004 and Asri et al., 2015). Moreover, foliar potassium application improves fruit marketable by increasing sugars content and vitamin C, this may be due to improved photosynthetic assimilation, their translocation from leaves to fruits and increased enzyme activation (Lester et al., 2007).

Interaction analysis for the obtained data of total sugars of tomato fruit, revealed that K-humate as foliar spray application seemed to be superior as revealed from the significant interaction illustrated in Table (8). Anyhow, the effect of $\mathrm{k}$-gluconate was more or less equal effect, obtained with total sugar content in tomato fruit, while it was more evident than control treatment.

Effect of some KNFs sources on sodium and potassium contents and $\mathrm{K}^{+} / \mathrm{Na}^{+}$ratio in tomato fruit:

As shown in Table (9) sodium content in tomato fruit and the ratio of $\mathrm{K}^{+} / \mathrm{Na}^{+}$with KNFs, showed that KNFs sources made $\mathrm{Na}^{+}$content less intense and significantly decreased it. Therefore, $\mathrm{K}^{+} / \mathrm{Na}^{+}$ratio increased. In this regard $K$ sources NFs under experiment gave $\mathrm{K}^{+} / \mathrm{Na}^{+}$ratio more than 1 with use of K-humate NFs. Factors affecting the uptake and distribution of $\mathrm{Na}^{+}$within the plants can have a predominant role in the response to K(Munns, 2002 and Zhu, 2003).

Generally, $\mathrm{Na}^{+}$content was significantly decreased more than control treatment. Data was noticeable that the ratio of potassium to sodium in all treatments was greater compared to the control treatment. Improving plant potassium absorption by using the spraying method and the appropriate 
Eman M. Abd El-Razik, et al.,

source of composting and nano-sized fertilizer at all rates led to a reduction in the competition between sodium and potassium. Potassium plays an important vital role in all cellular processes, and it is possible the presence of potassium to sodium in the plant juice gives the plant the ability to endure because the high concentration of sodium in humans of potassium leads to inhibiting the metabolism processes that depend on potassium (Abdelazizet al., 2019).

Table (8): Effect of some KNFs sources on total soluble sugars and vitamin C of tomato fruit quality

\begin{tabular}{|c|c|c|c|c|}
\hline Methods(M) & K sources(S) & Rates\%(R) & $\begin{array}{l}\text { Total soluble } \\
\text { sugar } \mathrm{mg} \mathrm{g}^{-1}\end{array}$ & $\begin{array}{c}\text { Vitamin C } \\
\mathrm{mg} 100 \mathrm{~cm}^{-3} \text { juice }\end{array}$ \\
\hline \multirow{10}{*}{ Soil } & Control & 100 & 40.56 & 143.48 \\
\hline & \multirow{4}{*}{ Humate } & 60 & 67.77 & 200.42 \\
\hline & & 30 & 68.43 & 202.15 \\
\hline & & 10 & 69.66 & 205.2 \\
\hline & & Mean & 61.61 & 187.81 \\
\hline & Control & 100 & 40.56 & 143.48 \\
\hline & \multirow{4}{*}{ Gluconate } & 60 & 54.95 & 166.78 \\
\hline & & 30 & 58.09 & 166.98 \\
\hline & & 10 & 58.99 & 168.55 \\
\hline & & Mean & 53.15 & 161.45 \\
\hline \multicolumn{3}{|c|}{ Mean } & 57.38 & 174.63 \\
\hline \multirow{10}{*}{ Foliar } & Control & 100 & 44.25 & 154.32 \\
\hline & \multirow{4}{*}{ Humate } & 60 & 78.15 & 278.2 \\
\hline & & 30 & 78.85 & 281.33 \\
\hline & & 10 & 80.05 & 283.17 \\
\hline & & Mean & 70.33 & 249.26 \\
\hline & Control & 100 & 44.25 & 154.32 \\
\hline & \multirow{4}{*}{ Gluconate } & 60 & 58.87 & 177.16 \\
\hline & & 30 & 61.34 & 177.45 \\
\hline & & 10 & 60.00 & 179.34 \\
\hline & & Mean & 56.12 & 172.07 \\
\hline \multicolumn{3}{|c|}{ Mean } & 63.23 & 210.67 \\
\hline \multirow{2}{*}{$\begin{array}{c}\text { Mean of } \\
\mathrm{K} \text { sources }\end{array}$} & \multicolumn{2}{|c|}{ Humate } & 65.97 & 218.53 \\
\hline & \multicolumn{2}{|c|}{ Gluconate } & 54.63 & 166.76 \\
\hline \multirow{4}{*}{$\begin{array}{l}\text { Mean of } \\
\text { rates \% }\end{array}$} & \multicolumn{2}{|c|}{100} & 42.41 & 148.90 \\
\hline & \multicolumn{2}{|c|}{60} & 64.68 & 205.64 \\
\hline & \multicolumn{2}{|c|}{30} & 66.68 & 206.98 \\
\hline & \multicolumn{2}{|c|}{10} & 67.18 & 209.07 \\
\hline LSD at 0.05 & $\begin{array}{c} \\
S \\
F \\
M \\
M \\
S \\
M S\end{array}$ & & $\begin{array}{c}15 \\
10 \\
2.5 \\
1.5 \\
7.5 \\
12.6 \\
6.3\end{array}$ & $\begin{array}{c}20 \\
13 \\
3 \\
2.6 \\
6 \\
3.9 \\
7.5\end{array}$ \\
\hline
\end{tabular}


Table (9): Effect of some KNFs sources on sodium and potassium contents and $\mathrm{K}^{+} / \mathrm{Na}^{+}$ ratio of fruit.

\begin{tabular}{|c|c|c|c|c|c|}
\hline Methods & K sources & Rates \% & $\mathrm{Na}^{+}$ & $\mathrm{K}^{+}$ & $\mathrm{K}^{+} / \mathrm{Na}^{+}$ratio \\
\hline \multirow{10}{*}{ Soil } & Control & 100 & 3.1 & 2.33 & 0.75 \\
\hline & \multirow{4}{*}{ Humate } & 60 & 2.18 & 3.28 & 1.51 \\
\hline & & 30 & 2.15 & 3.36 & 1.56 \\
\hline & & 10 & 2.11 & 3.45 & 1.64 \\
\hline & & Mean & 2.39 & 3.11 & 1.37 \\
\hline & Control & 100 & 3.1 & 2.33 & 0.75 \\
\hline & \multirow{4}{*}{ Gluconate } & 60 & 2.17 & 2.75 & 1.27 \\
\hline & & 30 & 2.12 & 2.87 & 1.35 \\
\hline & & 10 & 2.04 & 2.92 & 1.43 \\
\hline & & Mean & 2.36 & 2.72 & 1.20 \\
\hline \multicolumn{3}{|c|}{ Mean } & 2.37 & 2.91 & 1.29 \\
\hline \multirow{10}{*}{ Foliar } & Control & 100 & 3.09 & 2.53 & 0.82 \\
\hline & \multirow{4}{*}{ Humate } & 60 & 2.22 & 3.4 & 1.53 \\
\hline & & 30 & 2.18 & 3.48 & 1.6 \\
\hline & & 10 & 2.16 & 3.66 & 1.69 \\
\hline & & Mean & 2.41 & 3.27 & 1.41 \\
\hline & Control & 100 & 3.09 & 2.53 & 0.82 \\
\hline & \multirow{4}{*}{ Gluconate } & 60 & 2.28 & 2.83 & 1.24 \\
\hline & & 30 & 2.17 & 2.96 & 1.36 \\
\hline & & 10 & 2.12 & 3.12 & 1.47 \\
\hline & & Mean & 2.42 & 2.86 & 1.22 \\
\hline \multicolumn{3}{|c|}{ Mean } & 2.41 & 3.06 & 1.32 \\
\hline \multirow{2}{*}{$\begin{array}{l}\text { Mean of } \\
\text { K sources }\end{array}$} & \multicolumn{2}{|c|}{ Humate } & 2.40 & 3.19 & 1.39 \\
\hline & \multicolumn{2}{|c|}{ Gluconate } & 2.39 & 2.79 & 1.21 \\
\hline \multirow{4}{*}{$\begin{array}{l}\text { Mean of } \\
\text { rates \% }\end{array}$} & \multicolumn{2}{|c|}{100} & 3.10 & 2.43 & 0.79 \\
\hline & \multicolumn{2}{|c|}{60} & 2.22 & 3.07 & 1.39 \\
\hline & \multicolumn{2}{|c|}{30} & 2.16 & 3.17 & 1.47 \\
\hline & \multicolumn{2}{|c|}{10} & 2.11 & 3.29 & 1.56 \\
\hline
\end{tabular}

Effect of some KNFs sources on loss of available $K$ in soil depth:

Data in Table (10) show the effect of KNFs on loss of available $\mathrm{K}$ in soil depth. Regard to, the results, data showed that use of KNFs at two sources, foliar spray application at different rates reduced leaching the available $K$ at different depths of the soil under study.
Whereas, the results obtained that the control treatment (traditional $\mathrm{K}$ fertilizer at recommended doseat rate $100 \%$ ) was the highest available $K$ values loss in the soil with values were 220.14, 209.06 and $207.08 \mathrm{mg} \mathrm{K} \mathrm{kg}^{-1}$ and 212.15, 201.45 and $199.52 \mathrm{mg} \mathrm{K} \mathrm{kg}^{-1}$ at 0-30, 30-60 and 60-90 $\mathrm{cm}$ soil depths with soil and foliar spray application, respectively, (Mendes et al., 2016). 
Eman M. Abd El-Razik, et al.,

Table (10): Effect of some KNFs sources on loss of available $\mathrm{K}$ at soil depth.

\begin{tabular}{|c|c|c|c|c|c|}
\hline Methods(M) & K sources(S) & Rates\%(R) & $0-30 \mathrm{~cm}$ & $30-60 \mathrm{~cm}$ & $60-90 \mathrm{~cm}$ \\
\hline \multicolumn{3}{|c|}{ Background $\mathrm{K}$ in soil $\mathrm{mg} \mathrm{kg}^{-1}$} & 68.85 & 65.15 & 62.01 \\
\hline \multirow{10}{*}{ Soil } & Control & 100 & 220.14 & 209.06 & 207.08 \\
\hline & \multirow{4}{*}{ Humate } & 60 & 120.85 & 104.52 & 103.03 \\
\hline & & 30 & 55.42 & 51.37 & 48.2 \\
\hline & & 10 & 21.31 & 20.3 & 18.44 \\
\hline & & Mean & 104.43 & 96.31 & 94.19 \\
\hline & Control & 100 & 220.14 & 209.06 & 207.09 \\
\hline & \multirow{4}{*}{ Gluconate } & 60 & 135.75 & 128.41 & 125.22 \\
\hline & & 30 & 69.33 & 63.5 & 61.61 \\
\hline & & 10 & 33.73 & 31.52 & 28.54 \\
\hline & & Mean & 114.74 & 108.12 & 105.62 \\
\hline \multicolumn{3}{|c|}{ Mean } & 109.58 & 102.22 & 99.90 \\
\hline \multirow{10}{*}{ Foliar } & Control & 100 & 212.15 & 201.45 & 199.52 \\
\hline & \multirow{4}{*}{ Humate } & 60 & 115.86 & 106.91 & 95.47 \\
\hline & & 30 & 47.43 & 40.76 & 38.04 \\
\hline & & 10 & 9.32 & 5.69 & 4.28 \\
\hline & & Mean & 96.19 & 88.70 & 84.33 \\
\hline & Control & 100 & 212.15 & 201.45 & 199.52 \\
\hline & \multirow{4}{*}{ Gluconate } & 60 & 128.76 & 119.81 & 118.25 \\
\hline & & 30 & 59.88 & 53.21 & 50.49 \\
\hline & & 10 & 15.77 & 12.14 & 9.73 \\
\hline & & Mean & 104.14 & 96.65 & 94.50 \\
\hline \multicolumn{3}{|c|}{ Mean } & 100.17 & 92.68 & 89.41 \\
\hline \multirow{2}{*}{$\begin{array}{c}\text { Mean of } \\
\text { K sources }\end{array}$} & \multicolumn{2}{|c|}{ Humate } & 100.31 & 92.51 & 89.26 \\
\hline & \multicolumn{2}{|c|}{ Gluconate } & 109.44 & 102.39 & 100.06 \\
\hline \multirow[t]{4}{*}{ Mean of rates $\%$} & \multicolumn{2}{|c|}{100} & 216.15 & 205.26 & 203.30 \\
\hline & \multicolumn{2}{|c|}{60} & 125.31 & 114.91 & 110.50 \\
\hline & \multicolumn{2}{|c|}{30} & 58.02 & 52.21 & 49.59 \\
\hline & \multicolumn{2}{|c|}{10} & 20.03 & 17.41 & 15.25 \\
\hline \multicolumn{2}{|c|}{ LSD at 0.05} & $\begin{array}{c}\text { M } \\
\text { S } \\
\text { R } \\
\text { MS } \\
\text { MR } \\
\text { SR } \\
\text { MSR }\end{array}$ & $\begin{array}{l}1.5 \\
0.4 \\
0.6 \\
0.6 \\
0.9 \\
0.2 \\
0.5\end{array}$ & $\begin{array}{l}2.1 \\
0.6 \\
0.8 \\
1.3 \\
1.7 \\
0.5 \\
0.7\end{array}$ & $\begin{array}{l}0.7 \\
0.1 \\
0.5 \\
0.1 \\
0.4 \\
0.1 \\
0.3\end{array}$ \\
\hline
\end{tabular}

On the other hand, among the rates of KNFs in combined with different $K$ sources and application methods were differ in the loss of available $K$ with values were ranged between 4.28 to
$135.75 \mathrm{mg} \mathrm{K} \mathrm{kg}^{-1}$ at all soil depths under study (Hayyawi et al., 2019).

Therefore, data also, showed that treatment of K-humate NFs as K-humate NFs (foliar spray application) was more 
effect in combined with rate of $10 \%$ and the values were $9.32,5.69$ and $4.28 \mathrm{mg} \mathrm{K}$ $\mathrm{kg}^{-1}$ at $0-30,30-60$ and $60-90 \mathrm{~cm}$ soil depths, respectively.

The trend of available $K$ loss from different rates of KNFsin combined with different $K$ NFs sources used and application methods applied on tomato plants was observed as follow: $10<$ $30<60<100 \%$ (control treatment)(Al-juthery et al., 2019). While, the trend of available K NFs loss from different sources KNFs in combined with different rates of KNFs and application methods(soil and foliar) applied on tomato plants was observed as follow: K-humate NFs < K-gluconate NFs< control, also, foliar spray application less lost of available K NFs than soil application.

Fig (4) showed that the compare between control treatment and $10 \%$ rate of K-humate NFs at foliar application. Potassium associated with the highly soluble sources, may lead to high losses through leaching (Silva et al., 2002). So, Moraes and Dynia (1992) considered K as the most easily leached cation, due to its displacement to the soil solution and to its leaching.

So, a better conduct of the $\mathrm{K}$ nutrients that is essential to the plants and needful to enhance sustainable agriculture (Goulding et al., 2008). One of the methods that can be applied is use of foliar spray application by KNFs (Shehata et al., 2019 and Afify et al., 2019).

Using of the traditional potassium fertilizers with soil application, the spread of potassium to the roots is more complicated so potassium is subject to competition and interaction with other positive ions such as calcium, magnesium, sodium and hydrogen, which affects the movement and distribution of potassium (Fulton et al., 2010). While the nanofertilizers is characterized by slow release, accuracy of targeting, rapid absorption by roots, penetration into living tissues, avoiding sedimentation and adsorption reactions (Qureshi et al., 2018).

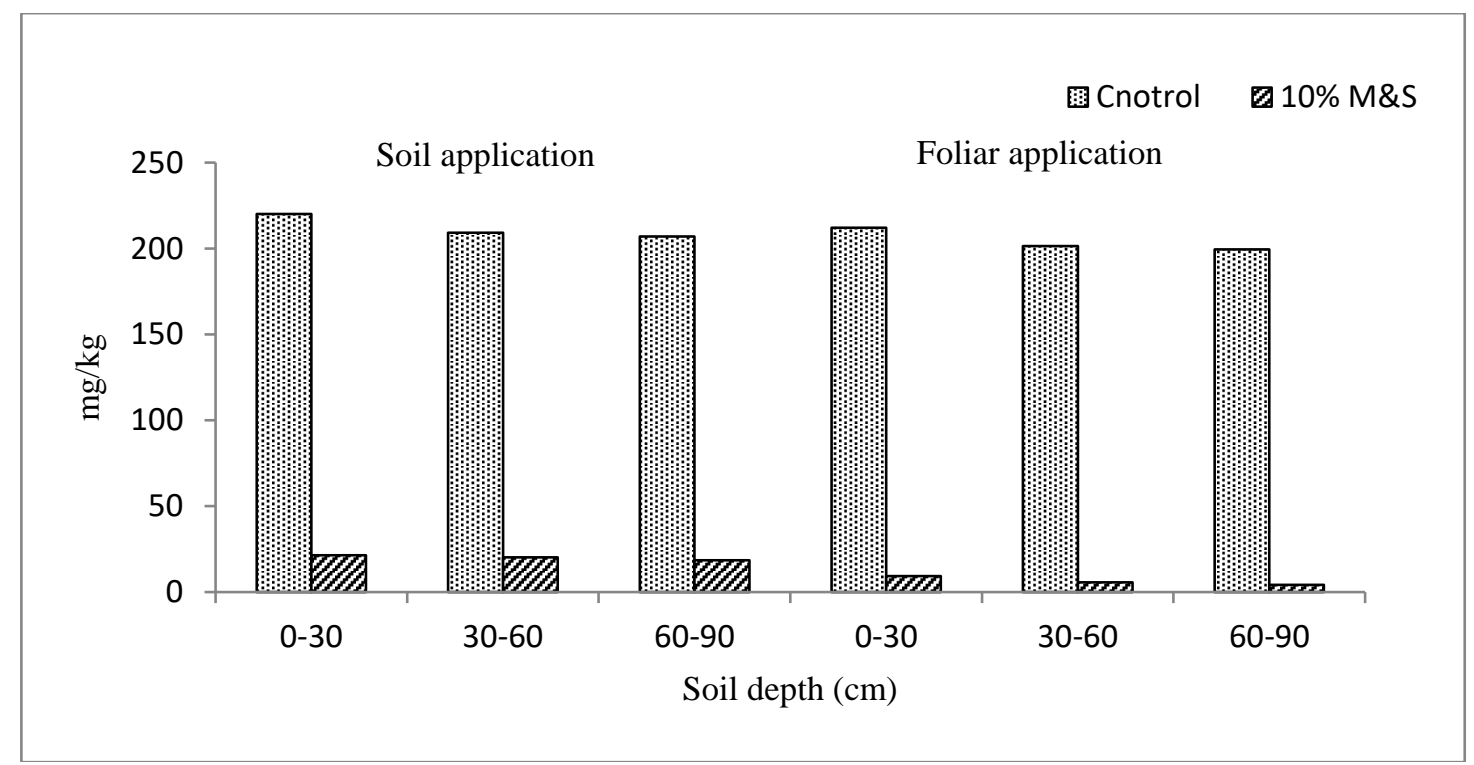

Fig (4): Compare between control, soil and foliar spray application with K-humate at rate of $10 \%$ for available $\mathrm{K}$ content loess in soil depth after tomato plants harvesting. 


\section{CONCLUSSION}

Could be concluded that, use of KNFs have been successful for better nutrition of crop plants compared to the conventional fertilizers. Use of KNFs as a foliar spray application on tomato plants leads to reduced in the amount of KNFs by $10 \%$ of recommended dose, use of $k$ humate NFs as K-humate of potassium fertilizer was more responsive to all plant parameters and use of KNFs as foliar spray application on the plant reduced available potassium loss through soil depths.

\section{REFERENCES}

Abdeldaym, E. A. (2019). Effect of foliar $\mathrm{ZnO}$ and $\mathrm{FeO}$ nanoparticles application on growth and nutritional quality of red radish and assessment of their accumulation on human health. In Agriculture (Pol'nohospodárstvo); 65(1): 16 - 29

Abdel Wahab,M. M., S. M.Abdelaziz, M. M. El-mogy and E. A. Abdeldaym(2019). Effect of foliar $\mathrm{ZnO}$ and $\mathrm{FeO}$ nano particles application on growth and nutritional quality of red radish and assessment of their accumulation on human health. Agriculture(Polnohospodárstvo); 65(1): 16-29.

Abdelaziz, M. E., M. E. Abdelsattar, E. A. Abdeldaym, A. M.Mohamed, M. A. M. Atia, A. M.Mahmoud, M. M. Saad and H. Hirt (2019). Piriformospora indica alters $\mathrm{Na}+\mathrm{K}+$ homeostasis, antioxidantenzymesandLeNHX1expres sionof greenhouse tomato grown under salt stress Scientia Horticulturae; 256: 1-7.

AbdelMonaim, M. F. (2012). Induced systemic resistance in tomato plants against Fusarium wilt diseases. Inter. Res. J. Microbiol. 3: 14-23.

Abul-Heba, G. A., G. M.Hussein and N. A. Abdalla (2008). Land bauforschung vTI. Agriculture and Forestry Research
1/2 (58):103-110.

Afify, R. R.,S. S. El-Nwehy, A. B. Bakry and M. E.Abd El-Aziz (2019).Response of peanut (Arachis hypogaea L.) crop grown on newly reclaimed sandy soil to foliar application of potassium nano-fertilizer. Middle East $J$. of Applied Sciences; 9: 78-85.

Al-juthery, H. W. A., R. A. H. G. Al-taee, Z. H. H .Al-Obaidi, E. A. H.Ali and Q. M. N. Al-Shami (2019). Influence of foliar application of some nano-fertilizers in growth and yield of potato under drip irrigation. IOP Conf. Series: Journal of Physics: Conf. Series; 1-9.

AOA C. (2012). Official Methods of Analysis, 18th ed. AOAC-Int., Arlington, VA.

Asri, F. O., E. I. Demirtas and N. Ari (2015).Changes in Fruit Yield, Quality and Nutrient Concentrations in Response to Soil Humic Ac id Applications in Processing Tomato. Bulgarian Journal of Agricultural Science, 21 (3): 585-591.

Azarpour, E., A. Karim, M. Motamed, M. Maral and H. R. Bozorgi (2012). Effects of bio, mineral nitrogen fertilizer management, under humic acid foliar spraying on fruit yield and several traits of eggplant (Solanum melongena L.) Afr. Agric. 7: 1104-1109.

Aziz, T., M. Rahmatullah, M. A. Maqsood, I. A. A. Tahir and M. A. Cheema (2006).Phosphorus utilization by six brassica cultivars (Brassica juncea L.) from tri-calcium phosphate, a relatively insoluble $\mathbf{P}$ compound. Pak. J. Bot.; 38:1529-1538.

Bidari, B. I. and N. S. Hebsur (2011). Potassium in relation to yield and quality of selected vegetable crops. Karnataka J. Agric. Sci.; 24(1): 55-59.

Cakmak, I. (2005). The role of potassium in alleviating detrimental effects of a biotic stresses in plants. J. Plant Nutr. Soil Sci.; 168: 521-530. 
Chapagain, B.P. and Z. Wiesman (2004). Effect of Nutri-Vant-PeaK foliar spray on plant development, yield, and fruit quality in greenhouse tomatoes. Sci. Hortic.; 102: 177-188.

Delfani, M., M. B. Firouzabadi, N. Farrokhi and H. Makarian (2014). Some physiological responses of black-eyed pea to iron and magnesium nanofertilizers. Commun. Soil Sci. Plant Anal.; 45: 530-540.

Ditta, A. and A. Arshad (2016). Applications and perspectives of using nanomaterials for sustainable plant nutrition. Nanotechnol Rev.; 5(2): 209-229.

Eleyan, Sohair, E. D., A. Abodahab Abdall, M. Abdallah Amany, and A. Rabeh Houda (2018). Effect of nitrogen, phosphorus and potassium nano fertilizers with different application times, methods and rates on some growth parameters of Egyptian cotton (Gossypium barbadense L.). Bioscience Research 15: 549-64.

Farnia, A. and M. Ezatollah (2015). Effect of soil and foliar application of humic acid on growth and yield of tomato (lycopersicon esculentum L.) .IJBPAS; 4(10): 706-716.

Ferrara, G. and Brunetti, G. 2010.Effects of the times of application of a soil humic acid on berry quality of table grape (Vitis vinifera L.) cv Italia. Spanish J. Agric. Res.; 8: 817-822.

Fulton, A., Advisor, F., Colusa, T. G. and Shasta, C. 2010. Primary Plant Nutrients: Nitrogen, Phosphorus and Potassium. 1-3.

Gomez, K. A. and A.A. Gomez (1984). Statistical Procedures for Agricultural Research.John Willey\& Sons, New York, USA.

Goulding, K., S. Jarvis and A. Whit more (2008). Optimizing nutrient management for farm systems.
Philosophical Transactions of the Royal Society; 363: 667-680.

Hawkesford, M., W. Horst, T. Kichey, H. Lambers, J. Schjoerring, I. S. Moller and P. White (2012). Functions of Macronutrients: Potassium. In: Marschner Petra. (Eds.), Marschner, s Mineral Nutrition of Higher Plants. Elsevier, Adelaide;.178-189.

Hayyawi, W. A., H. W. A. Al-uthery, M. N. Qusay and Q. M. N. Al-Shami (2019). Impact of fertigation of nano NPK fertilizers, nutrient use efficiency and distribution in soil of potato (solanum tuberosum I.). Plant Archives; 19(1): 1087-1096.

Hosseini, F. M., A. Aboutalebi, S. Eshghi, M. Dastyaran and F. Yosefi (2013). Foliar application of humic acid on quantitative and qualitative characteristics of 'Aromas' strawberry in soilless culture. Agri. Commun; 1:13-16.

IBM SPSS, (2020). Statistical package for the social sciences incorporation. Chicago, SPSS base application guide, Chicago.

Jackson, M. L. (1973). Soil Chemical Analysis. Prentice Hall of India Pvt. Ltd., New Delhi, 498.

Jackson, N. F., R. H. Miller and R. E. Forkiln (1973). Soil chemical analysis Prentic-Hall of India Private \& Ltd. New Delhi, 2nd Indian Rep.

Lester, G. E., J. L. Jifon and W. M. Stewart (2007). Foliar potassium improves cantaloupe marketable and nutritional quality. Better Crops; 91(1): 24-25.

Lindsay, W. I. and W.A. Norvell (1978). Development of DTPA soil test for $\mathrm{Zn}$, $\mathrm{Mn}$ and Cu. Soil Sci. Soc. Am. J., 24: 421-427.

Liu, R. and R. Lal (2015). Potentials of engineered nanoparticles as fertilizers for increasing agronomic productions. Sci. Total Environ.; 514: 131-139. 
Mahmoud, A. W. M., S. M. Abdelaziz, M. M. El-Mogy and E. A. Abdeldaym (2019). Effect of foliar $\mathrm{ZnO}$ and FeO nanoparticles application on growth and nutritional quality of red radish and assessment of their accumulation on human health. In Agriculture (Pol'nohospodárstvo); 65(1): 16 - 29.

Mahmoud, A. W. M. and Hend M. Swaefy (2020). Comparison between commercial and nano NPK in presence of nano zeolite on sage plant yield and its components under water stress Agriculture (Pol'nohospodárstvo); 66 (1): 24 - 39.

Mahmoud, A. W. M., A. B. El-Attar and A. A. Mahmoud (2017). Economic evaluation of nano and organic fertilizers as an alternative source to chemical fertilizers on carumcarvi plant yield and components. In Agriculture(Pol'nohospodárstvo);. 63(1): 33 - 49.

Mendes, W. C., J. A. Júnior, C. R. Paulo, P. C. R. Cunha, A. R. Silva, A. W. P. Evangelista and D. Casaroli (2016). Potassium leaching in different soils as a function of irrigation depths.R. Bras. Eng. Agríc. Ambiental; 20(11):972-977.

Merghany, M. M., Shahein, M. M., Mahmoud, A., Sliem, M. A., Abdelgawad K. F. and A. F. Radwan, (2019). Effect of nano-fertilizers on cucumber plant growth, fruit yield and it' s quality. Plant Archives Vol. 19, Supplement; 2: 165-172.

Mir, S. A., M. A. Shah, M. M. Mir and U. lqbal (2018). Breakthroughs in Research and Practice. (Chapter 10) New Horizons of nanotechnology in Agriculture and Food Processing Industry, Information Resources Management Association, IGI Global USA, Food Science and Nutrition; 196 $-217$.

Moraes, J. F. V. and J. F. Dynia (1992). Alterações nas características químicas e físico-químicas de um solo Gley Pouco Húmico sob inundação e após a drenagem. Pesquisa Agropecuária Brasileira, 27: 223-235.

Munns, R. (2002). Salinity, growth and phytohormones. In: A. Lauchli, and U. Luttge, eds. Salinity: Environment Plants - Molecules, Kluwer Academic Publishers, Dordrecht. 271-290.

Nouraein, M. (2019). Effect of nanofertilizers and biofertilizers on yield of maize: biplot analysis. sciendo j.; 25(2): 121-130

Owoso, O. F., O. Aluko and O. I. Banjoko (2000). Manual of food analysis and quality control. Concept publications Limited, Shomolu, Lagos.

Pearson, D. (1970). The Chemical Analysis of Foods, sixth ed. Chemical publishing Co. Inc, New York.

Piper, C. S. (1950). Soil and Plant Analysis Inter. Sci. Publisher Inc., New York, USA.

Prasad, R., V. Kumar and K. S. Prasad (2014). Nanotechnology in sustainable agriculture, present concerns and future aspects. Afr. J. Biotechnol.; 13: 705-713.

Qureshi, A., D. K. Singh and S. Dwivedi (2018). Nano-fertilizers: a novel way for enhancing nutrient use efficiency and crop productivity. Int. J. Curr. Microbiol. App. Sci.; 7(2): 3325-3335.

Rajaei, M. (2010). Plant Nutrition.Text booklet of Islamic Azad University of J.ahrom, Khayam Press.

Read, J.J., Raja Reddy K. and J. J. Jenkins (2006). Yield and fiber quality of Upland cotton as influenced by nitrogen and potassium nutrition.Euro. J. Agron.; 24: 282-290.

Richards, L. A. (1954). Handbook diagnosis and Improvement of saline and alkali soils.Agric.60, $U$. $S$. DEPT.166 pp.

Safavi, F. (2016). Effect of nano potassium fertilizer on some 
parchment pumpkin (Cucurbita pepo) morphological and physiological characteristics under drought conditions. Inter. J. Farm. Alli. Sci.; 5: 367-371.

Sajyan, T. K., S. M. Alturki and Y. N. Sassine (2020). Nano-fertilizers and their impact on vegetables: Contribution of Nano-chelate Super Plus ZFM and Lithovit-standard to improve salt-tolerance of pepper. Annals of Agricultural Sciences; 65: 200-208.

Salama, M. H. H. (2012). Effects of silver nanoparticles in some crop plants, common bean (Phaseolus vulgaris L.) and corn (Zea mays L.) Inter. Res. J. Biotechnology; 3: 190-197.

Shehata, S. A., M. M. El-Mogy and H. F. Y. Mohamed (2019). Post harvest quality and nutrient contents of long sweet pepper enhanced by supplementary potassium foliar application. International Journal of Vegetable Science; 25(2): 196-209.

Sher, A. and R. Abdur (2013). Response of tomato to nitrogen levels with or without humic acid. Sarhad J. Agric., 29(2): 43-54.

Shimaa, S. Zaki (2017). Evaluation of organic acids application on macro and micronutrients availability in some soils of Egypt and South Africa. M. Sc. Thesis, Institute of African Research and Studies, Soil Resources Dept. Cairo Univ., Egypt.
Silva, T. R. B., R. P. Soratto, M. Ozeki and O. Arf (2002). Manejo da época de aplicaçãopotássicaem arroz de terrasaltasirrigado por aspersãoem solo de cerrado. Acta Scientiarum; 4: 1455-1460.

Stewart, E.A. (1974). Chemical Analysis of Ecological Materials. Black- Well Scientific Publication, Oxford.

Sumanta, N., C. I.Haque, J.Nishika and R.Suprakash(2014).Spectrophotometri c analysis of chlorophylls and carotenoids from commonly grown fern species by using various extracting solvents. Res. J. Chem. Sci. 4(9): 63-69.

Tarafdar, J. C., S. Sharma and R. Raliya (2013). Nanotechnology, interdisciplinary science of applications. Afr. J. Biotechnol.;12: 219-226.

Wang, Q., D. J. Jacob, J. R. Spackman, A. E. Perring, J. P. Schwarz, N. Moteki and S. R. H. Barrett (2014). Global budget and radiative forcing of black carbon aerosol: Constraints from pole-to-pole (HIPPO) observations across the Pacific. Journal of Geophysical Research1; 19(1): 195206.

Wills, R. B. H. and V. V. Ku (2002). The use of $1-M C P$ to extend the time to ripen of green tomatoes and postharvest life of ripe tomatoes. Postharvest Biol. Technol, 26:85-90.

Zhu, J.K. (2003). Regulation of ion homeostasis under salt stress. Curr. Opin. Plant Biol.; 6: 441-445. 
Eman M. Abd El-Razik, et al.,

استخدام تقنية النانو لتقييم بعض مصادر البوتاسيوم وطرق تطبيقها على التربة والنبات معنات

إيمان محمد عبد الرازق،زينب حمدان عبد العزيز، أيمن عطفي عقل

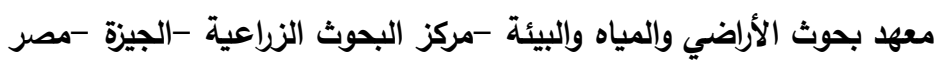

الملخص العربي

أجريت تجربة حقلية على تربة طينية بمحطة مركز البحوث الزراعية، الجيزة، مصر، تمت زراعتها بنباتات الطماطم

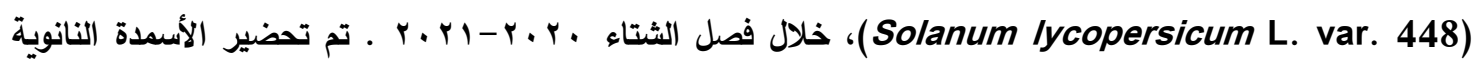
بالطحن الكروي وفصصها بواسطة المجهر الإكتروني الناقل (TEM) لقياس أحجام حبيبات سماد البوتاسيوم. تم تطبيق

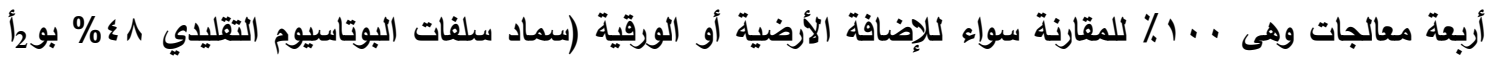

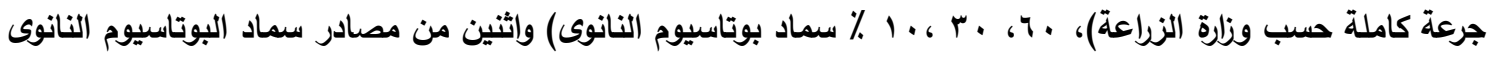

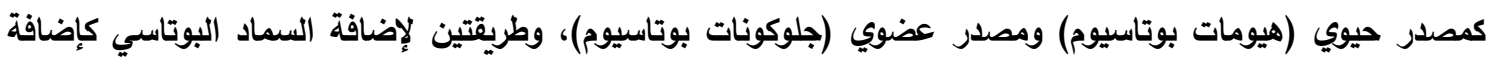

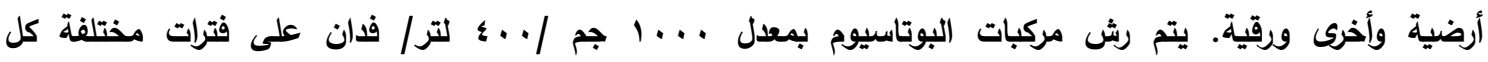

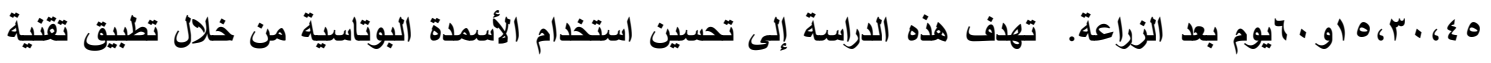

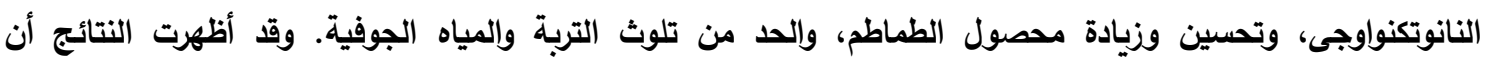

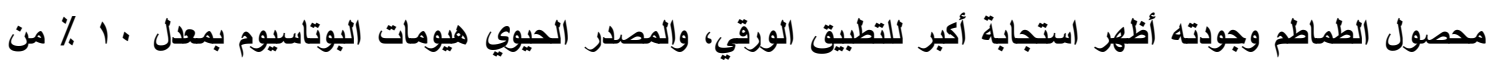

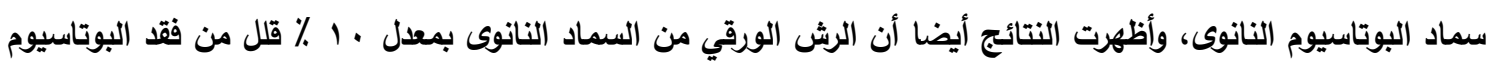
الميسر خلال أعماق التربة المختلفة تحت الدراسة.

أسماء السادة المحكمين

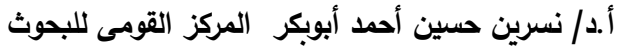

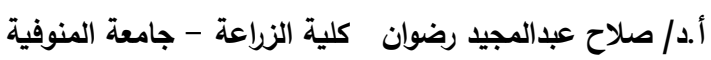

